\title{
Skab og medborgerskab
}

\author{
Nyegaard, Niels Perverse forbrydere og gode borgere: Homoseksualitet, \\ heteronormativitet og medborgerskab i Kobenhavns offentlighed, 1906-II \\ (diss.). Aarhus Universitet 2018 (453 sider)
}

SVERIGE OG DANMARK er pionerlandene for homoseksualitetens indførelse i Norden. Det skyldes især det tætte forhold og de udbyggede trafikale forbindelser til Tyskland, ikke mindst Berlin, homoseksualitetens epicenter i slutningen af i 8oo-tallet. Populært udtrykt ankom homoen med toget. Men tog kører som bekendt begge veje, og Sverige og Danmark importerede ikke kun teorier, romaner og sexologisk viden sydfra. Den tidlige danske homolitteratur blev typisk lynhurtigt oversat og eksporteret til Tyskland, da forfattere og forlæggere vidste, at der her var et købedygtigt og interesseret publikum. Denne udveksling af homokultur mellem Tyskland og Skandinavien kræver en videnskabelig udforskning.

Det er ikke emnet for Niels Nyegaards glimrende og interessante, men noget langstrakte ph.d-afhandling, der foretager et homo-, presseog medborgerskabshistorisk nedslag på en fuldkommen central periode, nemlig 1900-tallets første tiår, der både i Sverige og Danmark var en homoseksuel gründertid. Begrebet og fænomenet blev her for alvor et offentligt anliggende og for første gang i større udstrækning et emne for medierne, især aviserne, men også litteraturen og dramatikken. Anledningen var en række skandalesager, i Danmark som Den store Sædelighedsskandale i r906-I907, der fik længerevarende konsekvenser. Den startede banalt med anholdelsen af to yngre proletarmænd i en

(C) The authors. Published by Föreningen Lambda Nordica under the CC BY-ND license. 
baggård, som var mistænkt for indbrud, men i virkeligheden havde søgt at "begå uterlighed med hinanden". Herefter udviklede sagen sig, og en lang række personer blev anholdt og afhørt, og visse sågar dømt under pressens store bevågenhed.

Det opsigtsvækkende for især smudspressen, var både, at København nu havde udviklet en skjult homoseksuel subkultur, og at denne ikke kun omfattede medlemmer af arbejderklassen, men også fine borgere og sågar - blev det antydet - medlemmer fra adelen og - måske - selveste Prins Harald. Sidstnæunte viste sig ikke at stemme. To af de prominente dømte var en tandlæge, Emil Aae, der efter sin afsoning af en toårig fængselsstraf udgav en lille bog om affæren: Den fulde Sandhed om min Arrestation og fho. Kst. Kriminalretsassessor Wilcke's store Sadelighedssag, 1906-7, og en overbetjent Carl Albert Hansen Fahlberg, der udtalte sig om sagen i en artikelserie i Aftenbladet. Begge skildrer undersøgelseslederen Julius Wilcke som en uerfaren, overivrig skurk, der ikke videreførte gængs politipraksis med at se gennem fingre med, hvad voksne, myndige mænd foretog sig med hinanden. Ligesom lægerne arbejdede mange jurister for en afkriminalisering af homoseksualitet blandt samtykkende voksne. Senere skandaler handlede om en forstanderinde fra et indremissionsk pigehjem, der blev udhængt som lesbisk i pressen, hvorefter hun tog sin afsked, og en sag mod en homoseksuel, bedrageridømt vekselerer, der havde forbindelser til det svenske og danske kongehus.

Nyegaards projekt består af en grundig, præcis, pointeret og professionel undersøgelse af et udvalgt aspekt af denne periode: pressedækningen af affærerne i ni hovedstadsdagblade og otte småskrifter. Materialesamlingen rummer hele det politiske spektrum og demonstrerer, hvordan forskellige partier udnyttede homoseksualiteten til deres særlige formål og projekter. Venstrefløjen fokuserede på, hvordan homoseksualiteten især trivedes i overklassen, mens de "forførte" - og typisk betalte - proletardrenge og soldater fremstilledes som uskyldige ofre for borgerskabets besmittelse.

Særlige fokuspunkter for Nyegaard er medborgerskabets historie og bestræbelserne på at demokratisere og udbrede den almene valgret 
i I900-tallets første årtier. Han viser, hvordan konstruktionen af en homoseksuel "Anden" heteroseksualiserer medborgerskabet gennem sociologiske medborgerskabsteorier koblet med queerteori, postkolonial andetgørelsesteori og feministisk intersektionalitetsteori. Denne ramme fungerer glimrende og leder frem til analysen, der:

for det første betragter medborgerskab som et flerdimensionelt fænomen med tre centrale akser: udstrækning (fællesskab), indhold (pligter/ rettigheder) og dybde (handlinger). For det andet etablerer rammen et teoretisk blik, der antager, at disse aksers kobling til heteroseksualitet var en afledt effekt af den homoseksuelle figurs andetgørelse som en social outsider. (Nyegaard 2018, 449)

Denne eksotisering illustreres blandt andet af datidens mest berømte homo: Herman Bang, hvis "danskhed", der i den grad sås tvivl om. Ekstrabladet kan i slutningen af 1906 "spore" hans slægt til Ungarn og hans ophav til "omvankende Zigøjnere eller polske Handelsjøder" (I76). Netop denne henvisning giver anledning til en refleksion over projektets begrænsning og måske lidt snævre fokus på pressemateriale. For henvisningen er næsten uforståelig uden inddragelse af Bangs på det tidspunkt netop udgivne roman De uden Fedreland, hvor forfatteren iscenesætter sig selv som halvdansk grevesøn fra en unavngiven balkanø i Donau. Og kriminalromanens fader, Palle Rosenkrantz' presseplaidoyer for homoseksuelles retssikkerhed behandles, uden at det nævnes, at han i r 909 skrevet et homoseksuelt debatdrama om "Antinous" (der for øvrigt netop er genopudgivet som e-bog) (Heede 20r7a).

Nyegaards fravalg af medier som litteratur, drama, poesi og kunst resulterer således i et lidt amputeret tidsbillede. ${ }^{\mathrm{I}}$ Endvidere medtænker han slet ikke de illustrationer, karikaturtegninger (Heede m.fl. 2007) og fotografier, som typisk ledsagede artiklerne og klart har været styrende for læsningen. Her er Nyegaard for fokuseret på kun det trykte ord. Måske et klogt valg og en reflekteret begrænsning, men argumentationen for det mangler, hvilket kan undre, da afhandlingen ellers er ekstremt velargumenteret og lødig. 
Nyegaard afslutter med at understrege, at italesættelsen af den offentlige homoseksuelle figur forblev ustabil, og at forhandlingerne omkring den ikke er entydigt ekskluderende og andetgørende. På sigt peger de faktisk frem mod inklusion og medborgerskab. Men prisen er høj:

Den homoseksuelle figur var kun socialt inklusionsbar i det omfang, den holdt sine intimrelationer skjult i privatlivets mørke sammen med voksne og myndige partnere. På den måde markerede offentlighedens lejlighedsvise inklusioner af den homoseksuelle figurs [sic!] i det moderne danske medborgerskab en mindre entydig udfordring af dette medborgerskabs historiske heteroseksualisering. (45 I)

Medborgerskab og skab forudsætter hinanden.

Afhandlingen lægger sig smukt i forlængelse af den danske homohistoriografi, der indledtes med nyligt afdøde Wilhelm von Rosens pionerværk Månens kulør (1993) og fortsattes med Peter Edelbergs (2012) studier over 5o'erne og 6o'erne og Michael Nebeling Petersens (2012) studier af nyeste tid. Nyegaard skriver sig eksplicit ind i denne tradition, der citeres loyalt og præcist samt ikke mindst samvittighedsfuldt, som alt andet i denne sympatiske og grundige afhandling.

DAG HEEDE SYDDANSK UNIVERSITET

\section{REFERENCER}

Edelberg, Peter. 20I 2. Storbyen trakker: Homoseksualitet, prostitution og pornografi i Danmark 1945-1976. København: Jurist- og Økonomforbundets Forlag.

Heede, Dag. 2017a. "Antinous: Saint or Criminal?: Two Forgotten Danish Dramas." lambda nordica 22.4:17-39.

-. 20I7b. "'Det er Liv eller Død!': Homoseksuelle i dansk og norsk litteratur I880-I94I: En bioetisk undersøgelse af heteronarrativitet." Norsk litteraturvitenskapelig tidsskrift 20.r. https://www.idunn.no/nlvt/2or7/or/det_er_liv_eller_doed. 
Heede, Dag m. fl. 2007. Stoppet i farten: Herman Bang i karikaturens troldspejl. København: Gyldendal.

Nebeling Petersen, Michael. 20r 2: "Somewhere, over the rainbow: Biopolitiske rekonfigurationer af den homoseksuelle figure.” Ph.d.-afhandling, Københavns Universitet.

von Rosen, Wilhelm. I993. Månens kulør: Studier i dansk bøssebistorie I628-I9I2. København: Rhodos.

\section{NOT}

I. Jeg begik selv den modsatte synd, da jeg opsummerede periodens homolitteratur uden at medtage den umiddelbare historiske kontekst, der i visse tilfælde er næsten uomgængelig for at forstå samtidens dramaer og romaner (Heede $2017 \mathrm{~b}$ ). 